\author{
Ivan GAJDOŠ ${ }^{1}$ \\ Emil SPIŠÁK ${ }^{2}$ \\ Tomasz JACHOWICZ ${ }^{3}$ \\ Tomasz GARBACZ4
}

\title{
TENSILE PROPERTIES OF ADDITIVELY MANUFACTURED POLYETHERIMIDE PARTS
}

\begin{abstract}
This paper presents the results of a study of evaluating the influence of path generation strategy on tensile properties of samples made by additive manufacturing technology FDM (Fused Deposition Modeling). Several scientific studies were focused on the influence of path generation strategy on mechanical properties of deposited material. ABS and PLA are the most investigated materials used in FDM. This paper is aimed to determine the influence of selected path generation strategies on tensile strength of parts fabricated with ULTEM 9085 thermoplastic. The results obtained in experiments confirmed that proposed path generation strategy allowed to increase tensile strength by $25 \%$ compared to a situation when the samples were fabricated with default path generation setting.
\end{abstract}

Keywords: fused deposition modeling, tensile test, polyetherimide

\section{Introduction}

Nowadays, fused deposition modelling (FDM) and fused filament fabrication (FFF) are one of the most used additive manufacturing (AM) techniques due to its ability to manufacture parts with very complex geometries at relatively low prices. The main reasons for the growing popularity of AM techniques are their reliability, safe and simple fabrication process, low cost of material, and the availability to processing a variety of thermoplastics. The major research problem is to balance the ability to produce both tough and aesthetically pleasing products with their functionality.

\footnotetext{
1 Autor do korespondencji/corresponding author: Ivan Gajdoš, Technical University of Košice, Mäsiarska 74, 04001 Košice, Slovakia, e-mail: ivan.gajdos@tuke.sk

2 Emil Spišák,Technical University of Košice, Mäsiarska 74, 04001 Košice, Slovakia, e-mail: emil.spisak@tuke.sk

3,4 Tomasz Jachowicz, Tomasz Garbacz, Politechnika Lubelska, e-mails: t.jachowicz@pollub.pl, t.garbacz@pollub.pl
} 
In the FDM process, the material is initially in the raw form of a flexible filament. The filament is then partially heated above the melting (glass transition) temperature and extruded through a heated nozzle. The extrusion process is mostly conducted in environment with a controlled temperature. In lw cost systems instead of temperature controlled environment a heated platform is used. The material is extruded in a thin layer onto the building platform (first layer) or onto the previously built model layer on the building platform in the form of a prescribed two-dimensional $(x-y)$ layer pattern (fig. 1). The deposited material cools, solidifies, and bonds with adjoining material. After an entire layer is deposited, the build platform moves downward along the $z$-axis by an increment equal to the filament height (layer thickness) and the next layer is deposited on the top of it. The platen or table on which the build sheet is placed lies in the x-y plane.

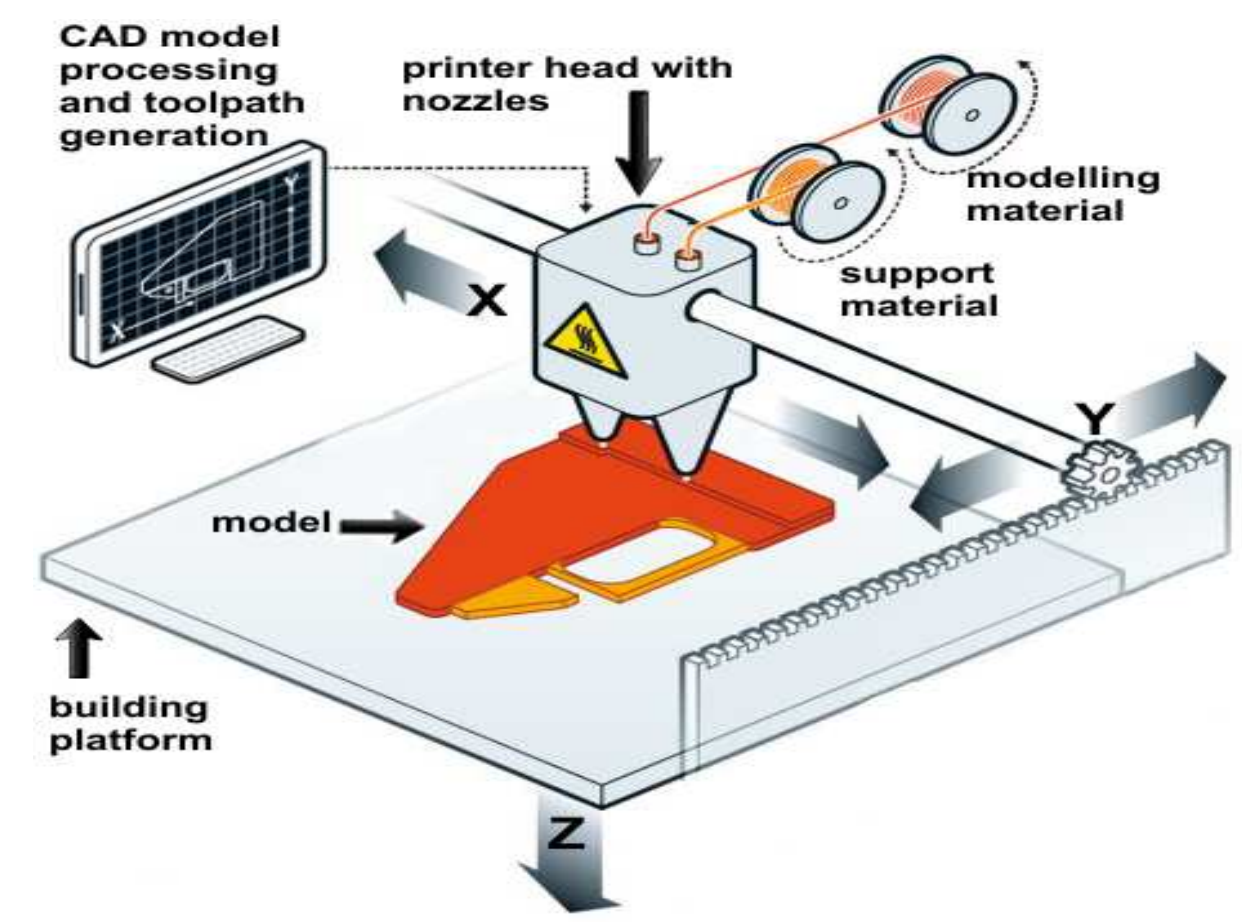

Fig. 1. Scheme of fused deposition modelling (FDM) process

Low cost or budget FFF systems are equipped only with one nozzle, and the supporting structure is fabricated with the same material as a model itself. This makes the support removal difficult for the operator. Mid-range and high level FDM systems generally come with two nozzles, one for model material and one for support material. Different properties of support material, cause lower interbond strength between model/support interface and thus easier to 
remove support structures after the model is built. Nowadays a wide variety of thermoplastics materials in a form of virgin materials, blends and composites are available for the FFF applications. Although AM is an efficient technology, full scale application has not gained much attention because of compatibility of presently available materials with AM technologies [1]. AM offers design and environmental advantages over classical manufacturing processes, the adoption of AM as a means for fabricating end-use components has been delayed by the technologies' narrow selection of available materials. The biggest part of materials used by modern AM technologies are polymers. There are also possibilities to use some metals (such as steel alloys and titanium) and ceramics. While there are presently available different types of polymeric materials that can be used in AM, the material properties are typically not as strong as their conventionally manufactured counterparts due to the anisotropy resulting from the layer-by-layer nature of the AM process [2].

AM is generally able to help to design and speed up the whole process of product development especially in the case when producing very complicated parts which production using traditional manufacturing methods would be challenging or even impossible. Designers use the possibility of design freedom to integrate function of several parts into one product. Pre-processing phase in interaction between CAD and AM system is mostly relatively seamless and there is less or no concern about interpretation of the design intent. AM system reduces lot of steps or stages necessary in the case of traditional manufacturing processes[3].

Manufacturing of complex shaped AM products with good aesthetically appealing with actually available AM technologies is not challenging. The problem is to produce AM parts that are functionally reliable, especially when building parts with geometry details on the edge of AM system resolution. Another issue is the inhomogeneity of mechanical properties caused by the nature of the layered manufacturing. This phenomenon had to be taken into account, when designing AM product, and is well known also in FDM technology. Lots of research studies results present the relationship between process setting conditions (raster angle, raster gap, deposition strategy, temperature, etc.) and the resulting mechanical properties[4-6]. These results show that the FDM produced parts are the most vulnerable when they are loaded in the z-building direction.

Although FDM is a very widespread technology, the manufacturer's policy often causes material incompatibly between individual FDM machines. Research studies mentioned above, solved the issue of mechanical properties for parts made of ABS, PLA or polycarbonate, which are the most commonly used materials in FDM technology. The presented study focuses on relatively rare used material in FDM technology ULTEM9085 $®$ supplied by Stratasys ${ }^{\circledR}$ (general polymer classification is polyetherimide - PEI). The goal of investigations was to determine one of the mechanical properties, namely tensile 
strength of FDM fabricated part. The part was produced under system`s default path generation strategy (PGS) and under proposed alternative strategy with an intention to minimize air gaps in the volume of the part. Alternative path generation strategy was adapted to specific conditions applicable for ULTEM 9085 in Insight ${ }^{\circledR} 9.1$ software. PGS is based on findings of Gajdoš et al. [7] who investigated samples made of polycarbonate, where the distribution of air gaps in the sample structure was not random. The structure of prepared samples was modified by locating air gaps in one part of the samples volume, thus significantly affecting tensile strength of the sample. The location of the air gaps in the volume is associated with the start point of layer raster forming (fig. 2).

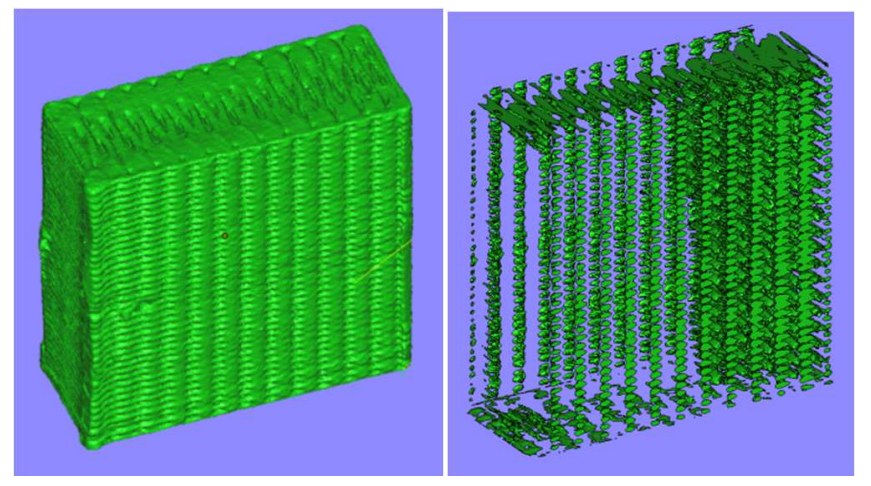

Fig. 2. Metrotomography 3D scanned FDM sample (left) and location of air gaps in the sample (right)

\section{Experimental procedure}

In this study, the samples made of ULTEM 9085 were prepared using Fortus $400 \mathrm{mc}^{\circledR}$ production system. Path generation strategy in pre-processing stage of the fabrication process was determined in Insight ${ }^{\circledR} 9.1$ software. The dimensions of the samples were in accordance with STN ISO 527-2 (fig. 3). All the samples were fabricated with orientation as presented in figure 4 .

This direction is recognized as the weakest for strength of FDM parts. The samples were prepared directly from prepared 3D STL model (dimensions are shown in figure 3) under the default setting of parameters values and slicing layer height of $0.254 \mathrm{~mm}$. Three types of path generation strategy were used with a raster angle of $45^{\circ}, 90^{\circ}$ raster angle between the following layers with a raster air gap of $0 \mathrm{~mm}$ and a raster width of $0.508 \mathrm{~mm}$. The samples differed only in the number of outlines (fig. 4). 

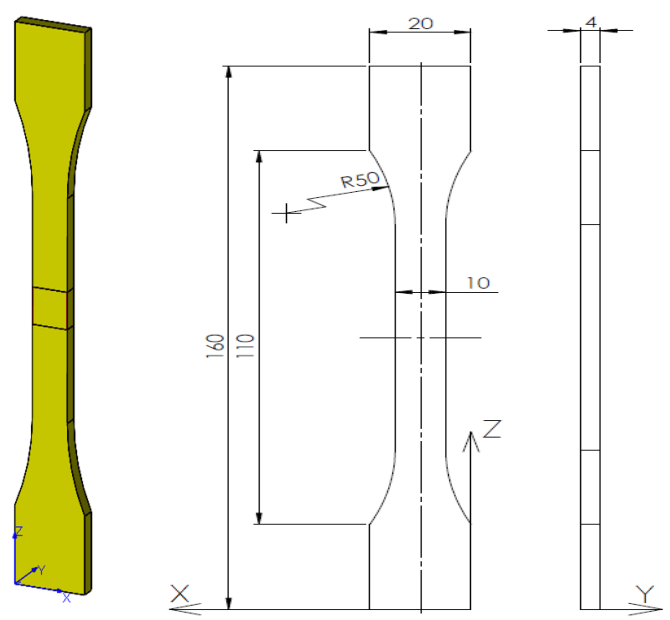

Fig. 3. Tensile test specimen dimensions, building orientation
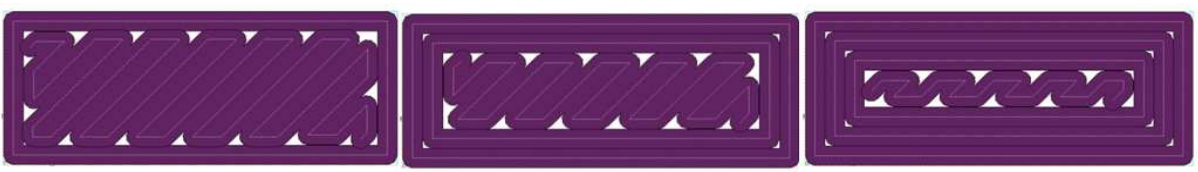

Fig. 4. Tensile test specimens default path generation strategy with one (left), two (middle) and three (right) outlines

Preparing samples with alternative path generation strategy required to modify designing and pre-processing procedures. There were some knowledge and software limitations which have been discussed in previous study [7]. As mentioned above, the cross-section area of the tensile test sample is relatively small, and consequently appearing fiber deposition leads to inhomogeneous air gap distribution (fig. 2). To avoid this phenomenon a plate was designed with the following dimensions: a thickness of $4 \mathrm{~mm}$, a height of $160 \mathrm{~mm}$, and a width of $100 \mathrm{~mm}$. Final shape of the test samples was machined on the milling machine.

Actual raster width setting and path generation strategy in Insight ${ }^{\circledR} 9.1$ for ULTEM 9085 and layer height of $0.254 \mathrm{~mm}$ do not allow to prepare desired alternative deposition strategy as shown in figure 5. Available raster widths cannot create combination of outline raster with $50 \%$ width of internal raster. Thus, the raster deposition strategy without outline was adopted and the desired offset between layers was obtained by modeling of layer offset directly in CAD model. Final path generation strategy setup was as follows: no outline, a raster width of $0.5 \mathrm{~mm}$, a raster angle of $0^{\circ}$ and a raster angle between layers of $180^{\circ}$. Five specimens were prepared for all types of samples used in the experiment which are listed in table 1. 


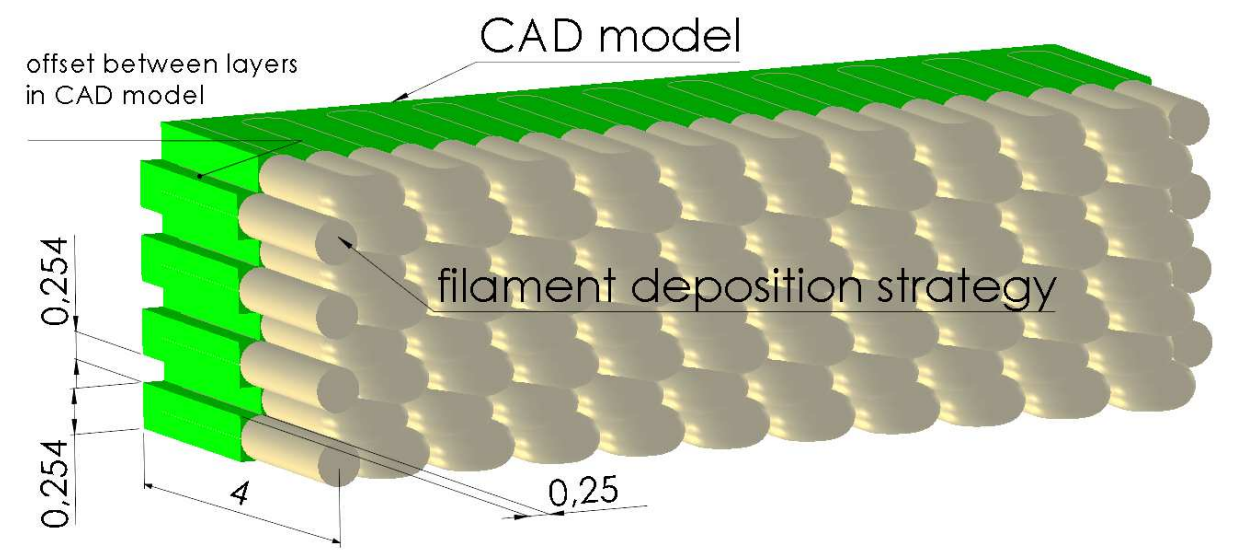

Fig. 5. CAD model of plate cross-section (green) and alternative filament deposition strategy

Table 1. Path generation strategies used in experiments

\begin{tabular}{|c|c|c|c|c|c|}
\hline $\begin{array}{c}\text { Sample } \\
\text { type }\end{array}$ & $\begin{array}{c}\text { Raster width } \\
{[\mathrm{mm}]}\end{array}$ & $\begin{array}{c}\text { Raster angle } \\
{\left[{ }^{\circ}\right]}\end{array}$ & $\begin{array}{c}\text { Raster angle between } \\
\text { following layers } \\
{\left[{ }^{\circ}\right]}\end{array}$ & $\begin{array}{c}\text { Number of } \\
\text { outline } \\
\text { contours }\end{array}$ & $\begin{array}{c}\text { Width of outline } \\
\text { contours [mm] }\end{array}$ \\
\hline $\mathrm{A}$ & 0.508 & 45 & 90 & 1 & 0.508 \\
\hline $\mathrm{B}$ & 0.508 & 45 & 90 & 2 & 0.508 \\
\hline $\mathrm{C}$ & 0.508 & 45 & 90 & 3 & 0.508 \\
\hline $\mathrm{D}$ & 0.500 & 0 & 180 & 0 & - \\
\hline
\end{tabular}

\section{Results and discussion}

The average values of ultimate tensile strength for all types of samples are presented in figure 6 . The tensile strength value for the sample "A" prepared with default settings was $36.64 \mathrm{MPa}$. Increasing of the number of outlines, decreases the resulting tensile strength to $34.71 \mathrm{MPa}$ in the case of the sample "B" and to $30.95 \mathrm{MPa}$ in the case of the sample "C". Increasing of the number of outlines has negative influence on resulting tensile strength. The highest tensile strength was measured for " $D$ " samples, made with alternative path generation strategy. Average value of $46.04 \mathrm{MPa}$ means improvement of tensile strength by $25.56 \%$, when compared with tensile strength of the sample "A".

In the figure 7 stress-elongation curves of selected samples determined through tensile tests are presented. Observed elongation at break for sample "D" is $3.14 \mathrm{~mm}$. Compared to other samples $(2.12-2.23 \mathrm{~mm})$ the elongation value is higher of about $40.08-48.11 \%$. It is assumed that the high layer to layer bond strength, allows utilizing bigger portion of filament elastic deformation capacity. 


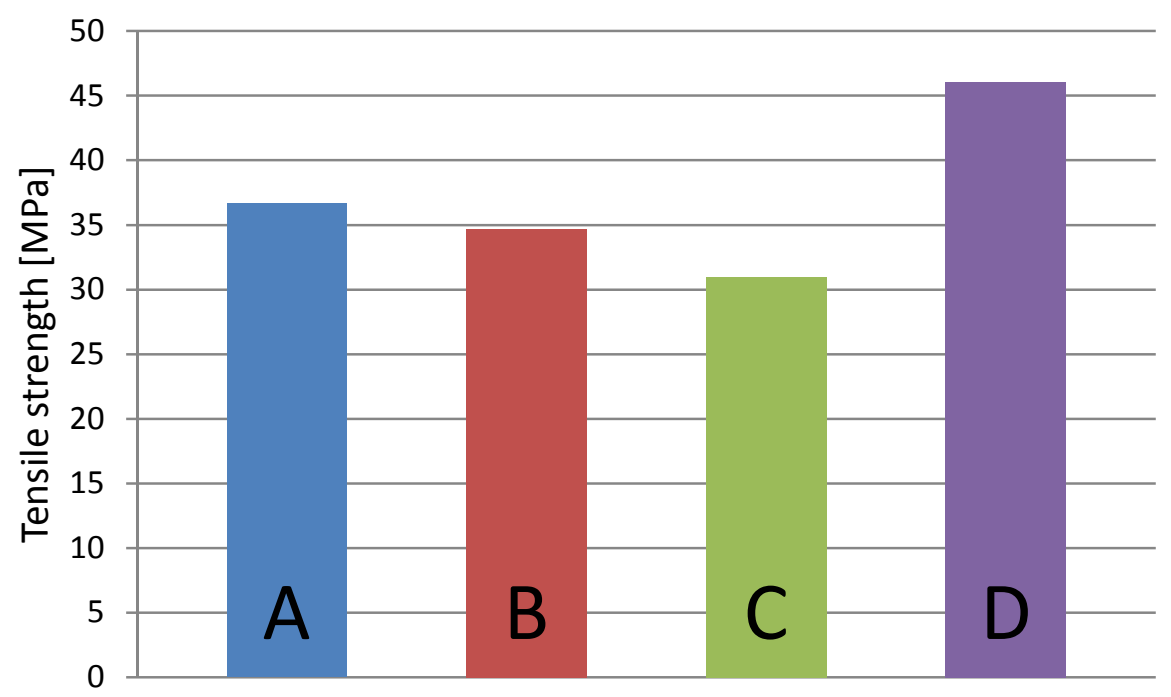

Fig. 6. Average tensile strength for all sample types

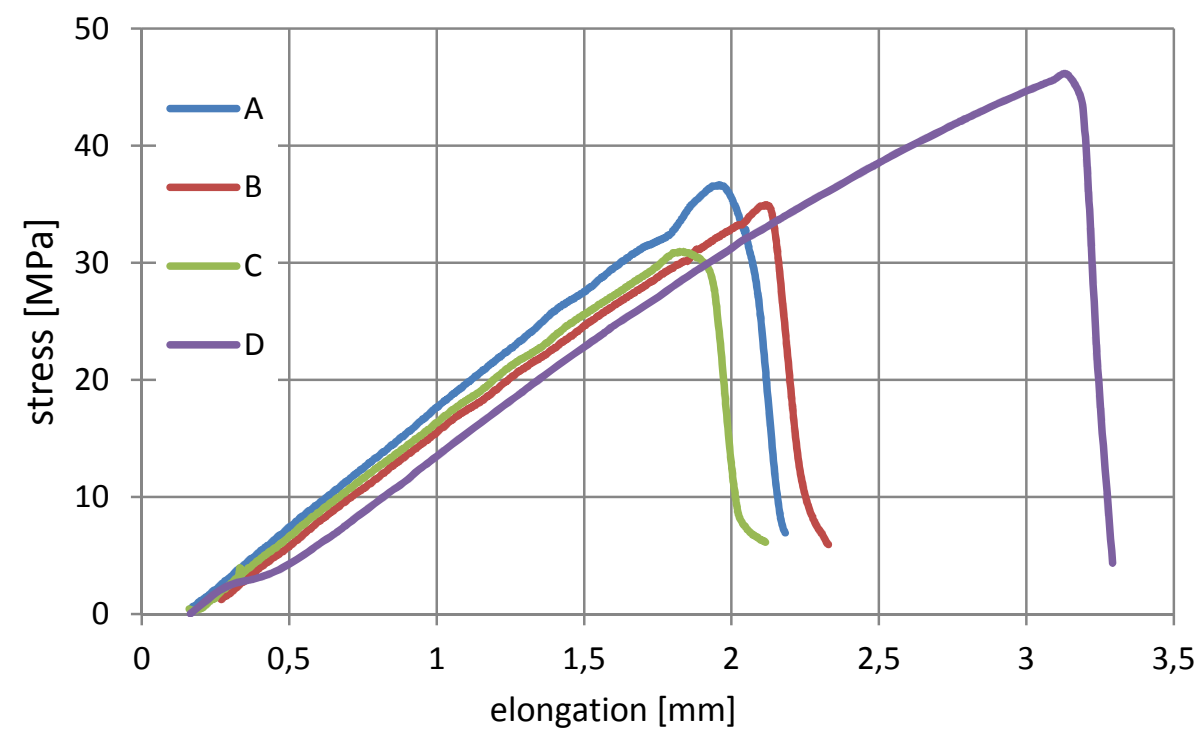

Fig. 7. Stress-elongation curves of tested samples determined through tensile tests

\section{Conclusions}

AM is able to help to design and speed up the whole process of product development, especially in the case when producing very complicated parts. Designers use the possibility of design freedom to integrate function of several 
parts into one product. The inhomogeneity of mechanical properties caused by the nature of the layered manufacturing is a main problem in AM products. This phenomenon had to be taken into account, when designing AM product, and is also well known in FDM technology. Generating a path deposition strategy for FDM parts with default settings causes fabrication of parts with relatively high amount of voids in the structure. The proposed alternative path generation strategy, had led to increasing of tensile strength by $26.56 \%$ and also increasing of elongation at break by $40.08 \%$. However, at this moment there are several challenges that have to be solved to apply this strategy when manufacturing FDM parts. Among others, actual slicing and path generating software do not incorporate into the developed alternative part generation strategy. In this study, the path generation is adopted in manually designed CAD model. For complex shaped parts this strategy would be nearly impossible, or very time consuming. The second problem is the inhomogeneity of airgaps distribution, which was solved in this study by printing the plate followed by machining of the samples. For practical purposes this is not applicable. Decreasing the surface quality of FDM parts is another drawback of proposed path generation strategy.

\section{Acknowledgement}

Authors are grateful for the support of experimental works by project VEGA no. $1 / 0872 / 14$

\section{References}

[1] Levy G. N., Schindel R., Kruth J. P.: Rapid manufacturing and rapid tooling with layer manufacturing (LM) technologies, state of the art and future perspectives, CIRP Annals: Manuf. Technol., 52 (2003) 589-609.

[2] Ivanova O., Williams C., Campbell T.: Additive manufacturing (AM) and nanotechnology: promises and challenges, Rapid Prototyping J., 19 (2013) 353-364.

[3] Gibson I., Rosen D. W., Stucker B.: Additive Manufacturing Technologies: Rapid Prototyping to Direct Digital Manufacturing, Springer, Heidelberg 2010.

[4] C. Onwubolu G., Rayegani F.: Characterization and optimization of mechanical properties of abs parts manufactured by the fused deposition modelling process, Int. J. Manuf. Eng., vol. 2014, Article ID 598531.

[5] Lipina J., Krys V., Sedlák J.: Shaped glued connection of two parts made by rapid prototyping technology, Appl. Mech. Mat., 2014, 541, 978-3-03835-111-5

[6] Sood A.K, Ohdar R.K., Mahapatra S.S.: Parametric appraisal of mechanical property of fused deposition modelling processed parts, Materials and Design, 2010, 287, 0264-1275.

[7] Gajdoš I., Slota J., Spišák E., Jachowicz T., Tor-Swiatek A.: Structure and tensile properties evaluation of samples produced by Fused Deposition Modeling, Open Engeneering 2016; 6:86-89, DOI 10.1515/eng-2016-0011. 


\section{WŁAŚCIWOŚCI MECHANICZNE PRZY ROZCIĄGANIU CZĘŚCI Z POLIETEROIMIDU WYTWARZANYCH W TECHNOLOGII PRZYROSTOWEJ}

\section{Streszczenie}

W artykule przedstawiono wyniki badań oceniających, w próbie rozciągania, wpływ strategii generowania ścieżki na właściwości mechaniczne próbek wytworzonych w technologii osadzania topionego materiału (ang. FDM - Fused Deposition Modeling). Liczne badania naukowe były skupione na wpływie strategii generowania ścieżki na właściwości mechaniczne materiału osadzanego. Najczęściej badanymi materiałami stosowanymi w technologii FDM są ABS oraz PLA. Celem niniejszego artykułu określenie wpływu wybranych strategii generowania ścieżki na wytrzymałość na rozciąganie elementów wytworzonych z termoplastu ULTEM9085. Wyniki badań eksperymentalnych potwierdziły, że proponowana strategia wytwarzania ścieżki pozwoliła zwiększyć wytrzymałość na rozciąganie o $25 \%$ w porównaniu z sytuacją, gdy próbki były wytwarzane przy użyciu domyślnych ustawień generacji ścieżki.

Słowa kluczowe: osadzanie topionego materiału, próba rozciągania, polieteroimid

DOI: $10.7862 / \mathrm{rm} .2016 .15$

Otrzymano/received: 24.05.2016 r.

Zaakceptowano/accepted: 14.07.2016 r. 